\title{
Why Do Companies Go Public? Evidence from the Prague Stock Exchange
}

\author{
Martina Skalická, Marek Zinecker, Adam P. Balcerzak, Tomáš Meluzín
}

\section{A B S T R A C T}

Objective: In this article, we intend to contribute evidence in regard to going public motivation on a sample of companies that launched an IPO at the Prague Stock Exchange between 2004 and 2017.

Research Design \& Methods: In order to evaluate the prevailing motives for the IPO launch, we design and apply a set of composite indicators the values of which may be understood as an indication of the extent to which IPO launch motives originate in the zone of the issuing company's needs or in the zone of interest of its owner (owners).

Findings: Our main conclusion is that the dominant going public motivation is to allow current shareholders to cash out and to enhance the company's publicity and image.

Implications \& Recommendations: Since the study disclosed that the prevailing motive of primary issues at the Prague Stock Exchange was the exit of investors and enhancing publicity and image we suggest that companies launching the Prague Stock Exchange in recent years were predominantly determined by non-financial aspects. Thus, the research findings represent substantial implications for issuers, investment bankers, the stock exchange, and macroeconomic policy makers when the concept of incentive schemes how to increase the attractiveness of the local capital market will be proposed.

Contribution \& Value Added: Our set of composite indicators allows to assess not only the predominant IPO motive zone, but also measure the intensity of the motives. This helps to understand better the urgency of the needs of the issuing companies satisfied by the IPO implementation.

\begin{tabular}{ll}
\hline Article type: & research article \\
Keywords: & Financial Economics; IPO; Prague Stock Exchange; IPO motivation \\
JEL codes: & G32, G29
\end{tabular}

Received: 6 November $2018 \quad$ Revised: 15 December $2018 \quad$ Accepted: 4 January 2019

\section{Suggested citation:}

Skalická, M., Zinecker, M., Balcerzak, A.P., \& Meluzín, T. (2019). Why Do Companies Go Public? Evidence from the Prague Stock Exchange. Entrepreneurial Business and Economics Review, 7(1), 181199. https://doi.org/10.15678/EBER.2019.070110 


\section{INTRODUCTION}

There is a generally shared definition that an initial public offering (IPO) is the very first sale of stocks to the public to raise capital, which allows the corporation to conduct a substantial expansion of its business activities. IPO implementation in its nature means raising external financing that is very often seen as a manner how to reduce leverage and thus bankruptcy risk as going public increases the equity ratio (e.g. Myers, 1984; Breinlinger \& Glogova, 2002; Kljucnikov \& Belas, 2016; Michalak, 2016; Ivanová, 2017; Valaskova, Kliestik, \& Kovacova, 2018; Mackevičius, Šneidere, \& Tamulevičienė, 2018; Zemguliene \& Valukonis, 2018).

Even after almost thirty years after the beginning of the economic transformation, the Czech capital market has remained underdeveloped compared to its well-developed counterparts in the European Union (Berk \& Peterle, 2016; Lyócsa, 2014). The financial market has been dominated by banks and the Prague Stock Exchange (PSE) has failed to fulfil one of the primary tasks the stock markets traditionally play, i.e. it fails to function as a place where companies would launch primary issues to raise equity (Meluzín, Zinecker, \& Lace, 2016; Balcerzak, Kliestik, Streimikiene, \& Smrčka, 2017).

The issue of external IPO drivers in the context of the Prague Stock Exchange (PSE) has been addressed, for instance, by Meluzín et al. (2017, 2018 a, b), Peterle and Berk (2016), Meluzín and Zinecker (2014), Lyócsa (2014) and Roženský (2008). These studies have emphasized that a small number of primary issues at the PSE is caused by the low liquidity of the domestic capital market as only a small volume of issues has been actively traded. Moreover, the current excess of liquidity in the banking sector resulting in accessible and cheap loans and financing provided by foreign parent companies have been discussed. Firm-specific factors represent another category of factors that might motivate a company to go public or deter it from launching public equity markets (Skalická Dušátková, Zinecker, \& Meluzín, 2017). The phenomena of information asymmetry, information disclosure, losing control over the company or IPO failure risk have received fairly substantial support in the academic studies (Myers, 1984; Myers \& Majluf, 1984; Chemmanur \& Fulghiery, 1999; Fontinelle, 2015; Isniawati, Rahmawati, \& Gunardi, 2018). In a survey based study, Meluzín, Zinecker and Lace (2016) deliver evidence that the most important IPO motivations among Czech companies include enhanced publicity and reputation and establishment of the firm's market value. Surprisingly, Czech companies do not feel motivated by raising external equity capital.

In this article we aim to contribute evidence in regard to going public motivation on a sample of companies that launched an IPO at the Prague Stock Exchange between 2004 and 2017 (initially, 2004 is the year when the first IPO was carried out at the PSE). This article differs from previous studies by the chosen research methodology consisting in designing and applying an original decision tree and a set of composite indicators, which serve as a tool for identifying whether the reason for the IPO launch is located in the investor's or the issuer's zone and whether the motives of the surveyed entities are of a financial or non-financial nature.

The research questions of this study are based on the motives of the IPO discussed in the academic literature and their insufficient mapping in the context of the Czech capital market. The research questions are as follows: In the case of the companies carrying out the IPO in the context of the Czech capital market, have there been predominant motives 
on the side of the issuer or its owner (owners)? Were the IPOs primarily motivated by raising capital or by reasons of non-financial nature?

We believe that the research results presented in this study will be of particular benefit to the stock exchange when formulating a strategy to increase the attractiveness of the organised capital market for issuers and investors. For the same reason, the results are inspiring for legislative and executive institutions, as a functioning capital market is undoubtedly a tool for increasing the country's economic potential, as stated in the 'Entrepreneurship 2020 Action Plan', approved by the European Commission (2012).

The rest of this article proceeds as follows. First, we provide an overview of the methodological approach. Next, we calculate financial ratios and interpret research findings. The final sections discuss and summarise the main conclusions.

\section{LITERATURE REVIEW}

Recently published studies on external factors that may have influence on IPO decision making examine explanatory power of GDP and industrial production growth, interest rates, sentiments on financial markets and regulatory constraints (e.g. Rydqvist \& Högholm, 1995; Ljungqvist, 1995; Ritter, 2011). Detailed academic research on IPO drivers on firm-specific level suggests that the decision to go public arises from corporate characteristics (size, age, the industry market-to-book ratio), as well as from the consequences public offerings have for investment and financial behaviour (Pagano Panetta, \& Zingales, 1998; Breinlinger \& Glogova, 2002). It should be remembered that these factors can differ depending on the region according to the degree of knowledge and information, as well as the efficiency of communication for the existing financing methods, as mentioned by Nicolescu and Tudorache (2017). In this context, the issue of financing or raising capital for projects through different strategies is one of the basic problems of corporate financial management (Vasilescu, Dima, \& Vasilache, 2009).

According to the pecking-order theory (Myers, 1984; Myers \& Majluf, 1984), raising capital via IPO comes into consideration when retained earnings, the financial resource with the lowest cost of capital and zero adverse-selection problems, and external capital in the form of bank loans have been exhausted. Thus, going public is interpreted as the last option how to raise capital as the cost of equity including IPO funds has been considered to be higher than the cost of debt financing (e.g. Pratt \& Grabowski, 2008).

The range of motives for the IPO launch may be, however, much broader than just 'merely' securing capital resources for further development. IPO objectives may not be of immediate financial nature. Helwege and Liang (2004) report that the IPO might also represent a form of the full or partial exit of the current owners who invested in the company at an early stage of its development, e.g. in the role of business angels or venture capitalists. A number of other studies indicate that the motives for the IPO launch may consist of trying to build public relations; this includes, for instance, the company's visibility in the media, the formation of the desired perception of the company in the public eye, or influencing the perception of the business sector in relation to its viability and risk (Brau, Francis, \& Kohers, 2003; Maksimovic \& Pichler, 2001; Mentel, Brożyna, \& Szetela, 2017). A possible IPO motive may consist in optimising the assets portfolio of the existing owners who retain control in the company, yet selling part of their shares allows them to release their capital tied up in the shares of the issuing company and subsequently used for other investments, 
repayment of debt, paying off the minority shareholders, etc. (Paeglis \& Veeren, 2013). As one of the motives of the IPO launch, Sullivan (1965) also mentions the possibility of using the issue proceeds for future mergers and acquisitions, extending the options to obtain additional financing in the future or increasing the attractiveness of the company when recruiting managerial talent through share options. From the perspective of the existing shareholders, the creation of a market with the shares of the issuing company serves as an important motive, resulting in increased liquidity (Kim \& Weisbach, 2008).

A number of studies emphasise the fact that IPOs are more common in fast growth sectors (Helvege \& Liang, 2004). The reason for the IPO launch may thus consist in the urgent need to make the necessary investments (or acquisitions) to maintain a position in the growing market and at the same time to reduce the risk carried by the current owners, as the rapid development of the industry / business usually reduces the capacity to predict further developments with sufficient precision.

Pagano et al. (1998) believe that the reason for the IPO does not simply lie in the financing of development investments; the primary motive is seen particularly in the effort to rebalance the capital structure of the company following a period of high investment and dynamic development. Pagano et al. (1998) further emphasise that going public improves the bargaining position towards banks and reduces debt costs as well as the share of bank finance in the capital structure. Auret and Britten (2008) emphasise that IPO yields are often used to repay existing debts.

Among other things, Brau, Francis and Kohers (2003) assume that the reason for the IPO launch may also include a fragmented ownership structure increasing the premium when taking over the company. Pagano et al. (1998), Brau and Fawcett (2006), Meluzín and Zinecker (2014), and Meluzín et al. (2016, 2018a,b) summarise the motives for the IPO launch as follows: they consider the financial motive to be the most frequent one, i.e. obtaining the funds for the purposes of development investments, acquisitions or financial restructuring. What is also equally important are non-financial motives stemming from the efforts to strengthen the bargaining position towards banks, increase the visibility of the company and raise the liquidity of the company shares.

The novelty of this study is twofold. On the one hand, it presents empirical evidence in regard to going public motivation on a sample of companies that launched an IPO at the Prague Stock Exchange in the last two decades. On the other hand, in this article we adjust and complement existing methodological approaches how to asses IPO motives by designing an original decision tree and a set of composite indicators.

\section{MATERIAL AND METHODS}

The research sample consists of IPOs carried out by private-sector business entities at the PSE in the period of 2004-2017. The year 2004 serves as the starting point of the research, as no primary issue was carried out at the PSE until 2004. The total number of IPOs realised at the PSE reached 11. Appendix A summarises the key characteristics of the conducted IPOs.

The source of data for analysis includes, in particular, the prospectuses of the issuers and their financial statements in the period before and after implementing the IPO. The data was taken from the Bloomberg database (2018). In addition to the methods specified below, the applied analytical methods include the content analysis of the documents, the analysis of the selected financial indicators, and the comparison method. 
Based on the literature dealing with the factors influencing the IPO implementation (e.g. Röell, 1996; Rydqvist \& Högholm, 1995) and the results of the previous empirical studies in the context of the Czech Republic (Meluzín, Zinecker, \& Lace, 2016), we defined a set of variables serving as a tool for identifying the reasons for the IPO launch using a sample of the examined companies. The results are subject to comparison with the officially declared prospectuses of individual issuers.

The development of selected variables (financial indicators) was examined up to two years before and two years after the IPO launch. Specifically, this includes the variables of 'Leverage', reflecting the development of the balance sheet total to equity, 'Size', reflecting the development of the balance sheet sum, 'Investment', expressing the development of long-term fixed assets, 'Currencies', expressing cash development, 'Loans', reflecting the development of interest-bearing debt, and 'Growth', expressing the development of sales. Table 1 summarises the examined variables and their calculation.

Table 1. Summary of examined variables and their calculation

\begin{tabular}{|c|c|}
\hline Variable & Definition/Calculation \\
\hline Leverage $_{(t-1)}$ & assets $_{(t-1)} /$ book value of equity $_{(t-1)}$ \\
\hline Leverage $_{(t+1)}$ & $\operatorname{assets}_{(t+1)} /$ book value of equity $(t+1)$ \\
\hline Size & $\operatorname{assets}_{(t+1)} / \operatorname{assets}_{(t-1)}$ \\
\hline Investment & ${\text { fixed assets }(t+1) / f_{i x e d} \text { assets }(t-1)}$ \\
\hline Currencies & currencies $_{(t+1) / \text { Currencies }_{(t-1)}}$ \\
\hline Bank & loans $_{(t+1)} /$ loans $_{(t-1)}$ \\
\hline Growth $_{(\mathrm{t}-1)}$ & ${\text { revenues }(t-1) / \text { revenues }_{(t-2)}}$ \\
\hline Growth & ${\text { revenues }(t+1) / \text { revenues }_{(t-1)}}$ \\
\hline Growth $_{(t+1)}$ & revenues $_{(t+2)} /$ revenues $_{(t+1)}$ \\
\hline
\end{tabular}

Source: own study.

The low index ( $t$ ) in the previous table indicates the moment (year) of the IPO launch; the index $(t-1)$ indicates the time of the last financial statements prior to the IPO implementation, and the index $(t+1)$ indicates the time of the financial statements immediately following the IPO launch. By analogy, the low indexes $(t-2)$ and $(t+2)$ indicate the dates of the second annual financial statements prior to / following the IPO implementation.

However, the size of the change in these indicators is not always a tool for identifying real motives on the part of the issuers. These are cases where actual intentions on the part of the issuers have not been fulfilled (see, for example, the lack of interest in the issue of Pivovary Lobkowicz Group or a sharp change in market conditions in the case of AAA AUTO Group N.V.). Thus, the intentions of issuers often face up to the constraints imposed by the development of external conditions. Therefore, for the purposes of assessing the IPO launch motives, we did not limit ourselves only to the parameters of the IPOs, but we also focused on the parameters defined in the issuer's prospectuses (which may not have always been completely fulfilled).

For this reason, the scope of our interest also includes studying the issuers' declarations (included in the prospectus) on the expected use of the capital raised by selling the shares. The evaluated information for assessing the reasons for the IPO launch included the issue structure (planned and actual), i.e. the portion of the offer of primary or secondary shares in the total offer. 
In the first phase, we focused on the question whether the motive for the IPO launch lay primarily in the issuer's zone or in the zone of its owner (having an influence on the issuer). On the basis of relevant literature and interviews with experts, the set of indicators shown in Table 1 was supplemented with the indicators evaluating the issue structure (Table 2). The assumed values of the indicators (at this stage expressed only by the range of assumed values) were assigned the source of the motive (in the issuer's zone or in the zone of its owner).

Table 2. IPO structure indicators

\begin{tabular}{|l|c|c|}
\hline \multicolumn{1}{|c|}{ Indicator } & Indicator value & Related motive \\
\hline \multirow{2}{*}{ Share of secondary stocks in the IPO value } & High & Motive in the owner's zone \\
\cline { 2 - 3 } & Low or zero & Motive in the issuer's zone \\
\hline \multirow{2}{*}{$\begin{array}{l}\text { Share of secondary stocks held by current sharehold- } \\
\text { ers before the IPO launch }\end{array}$} & High & Motive in the owner's zone \\
\cline { 2 - 3 } & Low & Motive in the issuer's zone \\
\hline IPO offer reduction in the section of primary stocks & - & Motive in the owner's zone \\
\hline IPO offer reduction in the section of secondary stocks & - & Motive in the issuer's zone \\
\hline Increasing the number of stocks after the IPO & High & Motive in the issuer's zone \\
\hline
\end{tabular}

Source: own study.

In order to assess the prevailing motives of the IPO launch, we proceeded using the following decision-making tree (Figure 1).

Does thelPO motive lie in the sphere of the issuer or its owner?

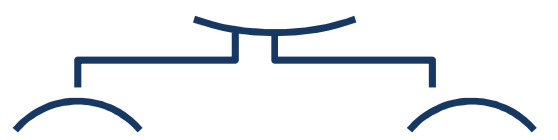

Motive in the issuer's sphere

Motive in the owner's

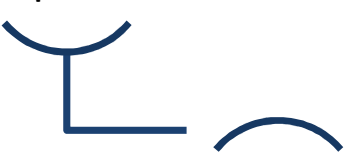
sphere

What is the issuer's motive?

What is the owner's

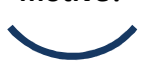
motive?

Figure 1. Decision-making tree for determining the prevailing motive of the IPO launch Source: own elaboration.

In order to answer the question on the first level of the decision-making tree, the composite indicators were defined combining three partial indicators as follows:

Zone motive importance $=($ IPO Share $) *($ IPO Size $) *($ IPO Reduction $)$

The first indicator is the portion of primary and secondary shares in the IPO value (IPO Share). The indicator may acquire the values in the interval of $\langle 0 ; 1\rangle$. The portion of secondary shares in the total offer is calculated as follows: 
where:

$$
\text { IPO Share }=\text { offer } /(\text { offer }+ \text { offer })
$$

offer $r_{p}$ - the number of primary shares;

offer - the number of secondary shares.

The second indicator represents the importance of the offer of primary or secondary shares. The basic measure consists in the number of shares already issued, to which the number of new shares in the primary offer and the number of shares sold by the investor are measured. The portion of secondary shares in the total offer may acquire the values from the interval $\langle 0 ; 1>$. The ratio between the number of primary shares and the number of shares already issued may acquire the values higher than one. Since realising the offer of primary shares also implies the abandonment of part of the control over the company by the original owners but to a lesser extent (a primary offer of $100 \%$ of the original shares means a loss of control of $50 \%$ of the voting rights; $200 \%$ of the original shares represents a loss of $2 / 3$ of the voting rights), the intended size of the portion of the primary shares offer is normalised with respect to the number of shares before the IPO at the interval $<0 ; 1)$. The loss of control is expressed as follows:

$$
\text { IPO Size }=s_{p} /\left(s_{p}+1\right)
$$

where:

IPO Size - the normalised size of the offer of primary shares in relation to the original number of shares before the IPO;

$s_{p}$ - the portion of the offer of primary shares in the total number of shares before the IPO.

The third indicator used for determining the IPO importance in terms of the existing owner or issuer is the manner of reducing the issue volume in the case of insufficient demand of subscribing investors. The level of insufficient interest may be expressed as the share of the actually sold shares within the IPO and the maximum intended number of sold shares within the IPO. This total level of insufficient interest in the IPO by subscribing investors may then be compared with the allocation of the subscription between the offer of primary and secondary shares (a higher reduction share in one part of the offer expresses a higher interest in the realisation in the second part of the offer). The share of the reduction in the part of the offer of primary shares and the total IPO offer may acquire the value in the interval $<0 ; \infty)$ :

$$
\text { Reduction ratio of primary offer }=r_{p} / r_{T}
$$

where:

$r_{p}$ - the ratio of the actually subscribed primary shares in the total offer;

$r_{T}$ - the ratio of the actually subscribed shares in the total offer.

The value 1 corresponds to the balanced reduction (in the same ratio) in the offer of primary shares and in the total IPO offer. Normalising this ratio to the interval $<0 ; 1)$ corresponding to other indicators will be reached by dividing the value of the indicator with itself and adding the value 1 in the denominator. The value 0.5 corresponds to the fact that satisfying the offer of primary (or secondary) shares is the same as satisfying the offer within the whole IPO; the values under 0.5 correspond to a lower allocation in the segment of the primary shares offer, while the values above 0.5 correspond to a higher allocation 
in the segment of the primary shares offer. Following the adjustments, the normalised indicator may be recorded as follows:

$$
\text { IPO Reduction }=r_{p} /\left(r_{p}+r_{T}\right)
$$

The combination of the three parameters specified above indicates whether the motivation for the IPO launch lies on the side of the issuing company or on the side of the selling investor. Offers of primary and secondary shares compete with each other. Increasing the number of shares in one of the offers jeopardises the successful implementation in the second part of the offer. Therefore, the share of individual offers in the total offer was monitored. The importance of the offer of the primary shares for the issuing company and the offer of the secondary shares for the existing owner is evaluated on the basis of the size of the existing owner's share before the IPO and the size of the issue. The ratio of offers to the size of the issue is used for this purpose. In the event that the issuer faces a limited interest in the offer, they decide which parts of the offer of shares (primary or secondary) should be given priority. In this case, it is an ex post indicator of the 'IPO importance'. Reducing the offer satisfaction in one of the segments indicates the importance of the IPO to satisfy the interests in the second segment.

We define the indicator of the power of interest on the issuer's side $\left(I_{p}\right)$ as follows:

$$
I_{p}=\frac{o f f e r_{p}}{o f f e r_{p}+o f f e r_{s}} * \frac{s_{p}}{s_{p}+1} * \frac{r_{p}}{r_{p}+r_{T}}
$$

By analogy, we define the indicator of the power of interest on the investor's side $l_{s}$ on the basis of the following formula:

$$
I_{S}=\frac{o f f e r_{s}}{o f f e r_{p}+o f f e r_{s}} * s_{p} * \frac{r_{s}}{r_{s}+r_{T}}
$$

Following the identification of the prevailing zone of the motive for the IPO launch (in the sphere of the issuer or the owner), the assessment focuses on the development of selected financial indicators of the issuing company (Table 1). This results in identifying the prevailing motive for the IPO launch, i.e. whether it is related to the issuing company or its owner. More specifically, attribution of motives is based on the ex post analysis of financial indicators and on the assumption that the indicators that changed significantly after the IPO launch could have been affected by the IPO or vice versa, their pre-IPO values led to the decision to carry out a primary share issue.

\section{RESULTS AND DISCUSSION}

In order to assess the primary motive of the IPO launch, i.e. whether it is located in the zone of the existing owners or the issuing company, we assessed the share of the planned offer of primary and secondary shares in the total issue. Table 3 (line 5) shows the ratio of the offer of primary shares. The table also contains further information on planned and actual parameters of the examined IPOs.

On the basis of the values of the indicators specified in Table 4, we assess whether the motives of the IPO implementation at the PSE in 2004-2017 prevailed in the zone of the issuing company or in the zone of the investor.

The results specified in Tables 3 and 4 imply that the motive to offer primary shares was the strongest in the case of the following companies: ECM, AAA and VGP. On the 
other hand, the motive to offer secondary shares was the strongest in the case of the following companies: companies Moneta, E4U, Fortuna and NWR. The balance of the motives may be identified in the case of: Pegas or Lobkowicz and Zentiva. A weak motive of the IPO implementation both on the side of the issuer and the existing owner may be identified in the case of the Kofola Company.

Table 3. Research results - IPO parameters at the PSE (plan vs. reality, in per cent)

\begin{tabular}{|c|c|c|c|c|c|c|c|c|c|c|c|c|}
\hline & Issuing Company & 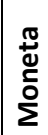 & 导 & $\begin{array}{l}\frac{0}{3} \\
0 \\
\frac{0}{0} \\
\end{array}$ & 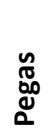 & 受 & 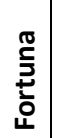 & 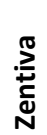 & $\sum_{\text {剀 }}$ & $\begin{array}{l}\frac{\pi}{0} \\
\frac{0}{0} \\
\underline{1}\end{array}$ & ज & $\frac{\pi}{4}$ \\
\hline & IPO year (20..) & 16 & 10 & 14 & 06 & 08 & 10 & 04 & 06 & 15 & 07 & 07 \\
\hline Par & ameter: & & & & & & & & & & & \\
\hline & Sale of the owner's share & 51 & 49 & 36 & $\begin{array}{l}3 \\
5\end{array}$ & 28 & 28 & 19 & 13 & 4 & 0 & 0 \\
\hline & Sale of the share in the overallotment & 59 & 49 & 45 & 44 & 33 & 32 & 25 & 13 & 9 & 0 & 0 \\
\hline$\frac{ᄃ}{\sigma}$ & $\begin{array}{l}\text { Ratio of the primary shares offer } \\
\text { in the issue value }\end{array}$ & 0 & 0 & 40 & 44 & 16 & 13 & 43 & 80 & 25 & 100 & 100 \\
\hline$\frac{\pi}{a}$ & $\begin{array}{l}\text { Ratio of the primary shares offer in the issue } \\
\text { value in the overallotment }\end{array}$ & 0 & 0 & 35 & 62 & 14 & 11 & 38 & 82 & 13 & 100 & 100 \\
\hline & Increase in the number of shares & 0 & 0 & 25 & 27 & 5 & 4 & 15 & 52 & 1 & 22 & 36 \\
\hline & $\begin{array}{l}\text { Increase in the number of shares } \\
\text { in the overallotment }\end{array}$ & 0 & 0 & 25 & 27 & 5 & 4 & 15 & 57 & 1 & 25 & 39 \\
\hline & Sale of the owner's share & 59 & 49 & 2 & 44 & 33 & 32 & 25 & 13 & 6 & 0 & 36 \\
\hline & $\begin{array}{l}\text { Ratio of the primary shares offer } \\
\text { in the IPO value }\end{array}$ & 0 & 0 & 91 & 36 & 14 & 11 & 38 & 82 & 18 & 100 & 100 \\
\hline$\frac{ \pm \pi}{\pi}$ & Increase in the number of shares & 0 & 0 & 25 & 24 & 5 & 4 & 15 & 52 & 1 & 24 & 36 \\
\hline $\mathscr{\sim}$ & $\begin{array}{l}\text { Share of the original shareholders } \\
\text { in the registered capital after the issue }\end{array}$ & 41 & 51 & 78 & 45 & 64 & 65 & 66 & 57 & 93 & 81 & 74 \\
\hline & Fulfilling the IPO intention (Yes/No) & $\mathrm{Y}$ & $\mathrm{Y}$ & $\mathrm{N}$ & $\mathrm{Y}$ & $\mathrm{Y}$ & $\mathrm{Y}$ & $\mathrm{Y}$ & $\mathrm{Y}$ & $\mathrm{Y}$ & $\mathrm{Y}$ & $\mathrm{Y}$ \\
\hline
\end{tabular}

Source: own study.

Table 4. Zone of the IPO motive at the PSE (plan vs. reality)

\begin{tabular}{|c|c|c|c|c|c|c|c|c|c|c|c|}
\hline Indicator & 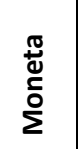 & 守 & $\begin{array}{l}\text { No } \\
\frac{0}{3} \\
\frac{0}{0} \\
\end{array}$ & 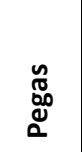 & $\sum_{\mathbf{z}}^{\frac{\kappa}{2}}$ & 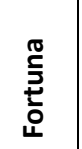 & 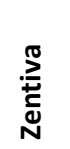 & $\sum_{\mathrm{u}}$ & $\begin{array}{l}\frac{\pi}{0} \\
\frac{0}{0}\end{array}$ & ज़ & $\frac{8}{4}$ \\
\hline$I_{p}-$ issuer's interest & 0 & 0 & 0.06 & 0.08 & 0 & 0 & 0.03 & 0.23 & 0 & 0.13 & 0.20 \\
\hline$I_{s}-$ owner's interest & 0.29 & 0.25 & 0.04 & 0.09 & 0.14 & 0.14 & 0.08 & 0.01 & 0.04 & 0 & 0 \\
\hline $\mathrm{I}_{\mathrm{p}}-\mathrm{I}_{\mathrm{s}}$ & -0.29 & -0.25 & 0.02 & -0.01 & -0.14 & -0.14 & -0.05 & 0.22 & -0.04 & 0.13 & 0.20 \\
\hline
\end{tabular}

Source: own study.

In the case of Moneta and E4U, the ratios of the planned offer of primary and secondary shares obviously indicate that the primary motive of the IPO launch was in the zone of the existing owner (shareholder). In the first case, $51 \%$ share of the original owner is sold, and in the second case $49 \%$ share of the original owner is sold without offering any primary shares. On the contrary, the primary IPO motive in the issuer's sphere may 
be unambiguously identified in the case of the VGP and AAA Companies. Within these IPOs, the offer of secondary shares was not realised (or even planned) and all the IPO proceeds (after deducing transaction costs) served to increase the registered capital of the issuing company. A similar result ( $91 \%$ of the offer of primary shares) may be identified in the case of Pivovary Lobkowicz, where the actual result, however, does not correspond to the intention. According to the prospectus, the intended ratio of the primary shares offer in the IPO value amounted to mere $35 \%$ (in the overallotment). Owing to the insufficient demand for shares, however, the issuing company and the owner preferred the interest of the company. In the case of the remaining issues, the motives of the IPO launch may be seen both in the zone of the issuer and its owners.

If we consider the IPO motives from the perspective of the existing shareholders who wish to sell their share, the criterion for assessing the fulfilment of this intention consists in the size of the sold share in the registered capital. If we consider the IPO importance from the issuer's perspective, where raising capital is perceived as a key motive, the assessment criterion includes the size of the offer of primary shares in relation to the number of shares before the IPO (other measures, such as the financial effect of the IPO in relation to the registered capital of the issuing company or the balance sheet sum of the issuer after the IPO, may also be considered).

Table 3 shows the IPOs ranked in the descending ratio of the offer of secondary shares in the ownership interest of the existing shareholders. In the case of Moneta and E4U, the results imply high ratios of the offer of secondary shares in the IPO value. In the case of the Pivovary Lobkowicz and Pegas Companies, the ratio of the secondary shares offer in the ownership of the existing shareholders also reaches high values (under the overallotment of $45 \%$ or $44 \%$ respectively), nevertheless, these cases are marked with the combination with the interest in the issuer's zone (the ratio of the primary shares offer in the IPO amounts to $35 \%$ and $62 \%$ respectively under the overallotment). The intended increase in the number of shares as a result of the primary shares offer reaches high values (Table 3, line 6) in comparison with the IPOs consisting only of the offer of primary shares (VGP or AAA). The intention was not completely fulfilled even in the case of Pivovary Lobkowicz and Pegas. In the case of Pegas, the plan was fulfilled at 95\%, while it was reduced mainly in relation to the target in the issuer's zone. In the case of Pivovary Lobkowicz, however, the plan was fulfilled at merely $39 \%$, whereas the target in the issuer's zone was fully preferred. The indicators shown in Table 6 serve to specify the IPO motives (the zone of the issuer or the existing owner - shareholder).

Using the values of the financial indicators and their changes (Table 5), we may draw inferences on the likely IPO motives. In the case of Pegas and Pivovary Lobkowicz, the likely motive seems to be the efforts to change the financial structure. In the case of Pegas, the leverage value reached 18.3 before the IPO. Pivovary Lobkowicz even had the negative equity. Following the IPO, neither company saw an increase in the assets (size) or a substantial increase in revenues (in the case of Pivovary Lobkowicz, revenues were stagnating, while in the case of Pegas, the growth rate weakened). In the case of these issuers, the primary IPO motive may be seen as stabilising the financing structure.

The third IPO group with common features includes the issues of NWR and Fortuna. For both IPOs, the offer of secondary shares represents approximately $1 / 3$ of the ownership interest of the existing shareholders and an increase in the number of shares in the 
post-implementation phase is only $4 \%$ or $5 \%$, respectively. The ratio of primary shares in the IPO value is limited in both cases ( $11 \%$ and $14 \%$ respectively under the overallotment). The IPO for NWR seems to have served to reduce leverage. However, the IPO yields were not used to reduce indebtedness, but for operating purposes (the growth of long-term assets lags behind an increase in the balance sheet sum). Although the company's sales were growing at a high pace, the physical volume of production did not change significantly (the sales growth was influenced by rising coal prices).

Table 5. Development of selected financial indicators of the issuing companies in the period before and after the IPO at the PSE

\begin{tabular}{|c|c|c|c|c|c|c|c|c|c|c|}
\hline Issuing Company & 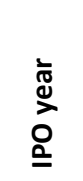 & 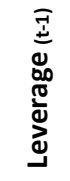 & 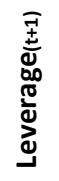 & $\stackrel{N}{n}$ & 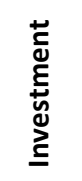 & 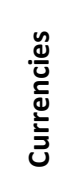 & 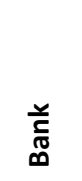 & 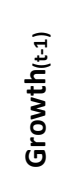 & 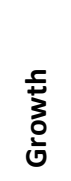 & 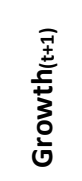 \\
\hline Zentiva & 2004 & 3.2 & 1.3 & $9 \%$ & $10 \%$ & $-19 \%$ & $-93 \%$ & $27 \%$ & $\mathrm{~N} / \mathrm{A}$ & $6 \%$ \\
\hline Pegas (2006) & 2006 & 18.3 & 3.2 & $-1 \%$ & $2 \%$ & $-22 \%$ & $-19 \%$ & $50 \%$ & $10 \%$ & $1 \%$ \\
\hline Pegas (2007) & & & 2.8 & $4.8 \%$ & $17 \%$ & $-98 \%$ & $-26 \%$ & & & \\
\hline ECM & 2006 & $\mathrm{~N} / \mathrm{A}$ & 3.8 & & & & & & & \\
\hline AAA (2007) & 2007 & 5.6 & 4.1 & $57 \%$ & $69 \%$ & $85 \%$ & $33 \%$ & $29 \%$ & $35 \%$ & $-23 \%$ \\
\hline AAA (2008) & & & 9.8 & $0 \%$ & $20 \%$ & $6 \%$ & $5 \%$ & & & \\
\hline VGP & 2007 & 1.8 & 3.1 & $42 \%$ & $76 \%$ & $-92 \%$ & $53 \%$ & & & \\
\hline NWR & 2008 & 5.4 & 3.5 & $11 \%$ & $2 \%$ & $43 \%$ & $-4 \%$ & $11 \%$ & $49 \%$ & $-45 \%$ \\
\hline Fortuna & 2010 & 3.0 & 1.8 & $-21 \%$ & $-29 \%$ & $17 \%$ & $-26 \%$ & $-6 \%$ & $-7 \%$ & $9 \%$ \\
\hline Pivovary Lobkowicz & 2014 & -2.6 & 1.4 & $-9 \%$ & $-10 \%$ & $11 \%$ & $-57 \%$ & $0 \%$ & $-1 \%$ & $0 \%$ \\
\hline Kofola (2015) & 2015 & 2.9 & 3.0 & $-0 \%$ & $2 \%$ & $241 \%$ & $121 \%$ & $14 \%$ & $-2 \%$ & $-2 \%$ \\
\hline Kofola (2016) & & & 2.9 & $35 \%$ & $18 \%$ & $150 \%$ & $115 \%$ & & & \\
\hline
\end{tabular}

Source: own study.

In the case of Fortuna, there were significant changes in the structure of assets and liabilities due to accompanying transactions related to the IPO preparation. The impact of the IPO on the capital structure may thus be assessed as limited. The company did not record a significant sales growth, either. Similarly to NWR, even in this case, the offer of primary shares may be perceived as complementary to the secondary shares offer. The investor's exit seems to be the decisive motive of the IPO implementation. In such a case, the IPO may be affected by the attempts to act on prospective buyers in the sense of future plans and perspective of the issuer; however, the owner makes use of the benefits owing to the information asymmetry and sells overpriced shares (Ritter, 1991; Loughran \& Ritter, 1995).

With its ratio of the offer of primary and secondary shares, the IPO of the Zentiva Company corresponds to the IPOs of Pivovary Lobkowicz and Pegas. The IPO appears to be insignificant, both from the point of view of the issuing company and the existing owner. The intention of the existing shareholder was to sell not more than $25 \%$ of its stake in the issuer's company (vs. 44-45\% in the case of Pegas and Pivovary Lobkowicz) and the expected maximum increase in the number of shares amounted to $15 \%$ (vs. 25-27\% for Pegas and Pivovary Lobkowicz). The motives for IPO implementation can therefore be considered less intense in the case of Zentiva, albeit similar. The investor pursued a partial exit and, in the case of the 
issuer, the main reason consisted in the change in the financial structure (reduction of financial leverage and repayment of interest-bearing debt), as well as the need for the growth of the company (reflected in assets growth, fixed assets growth and sales growth).

In the case of ECM, the intended ratio of the primary shares offer reached up to $82 \%$ under the overallotment. This makes the issue unequivocally different from other combined offers, thus approaching the IPOs with the offer of primary shares (VGP or AAA). The investor intended to sell $13 \%$ of their original shareholding, while the primary offer could reach up to $57 \%$ of the increase in the number of shares (the highest out of the examined values). It may thus be stated that the primary motive for the IPO implementation lay in the issuer's sphere (which is also reflected in the value of the Ip-Is indicator). The issuing company recorded a significant increase in the balance sheet sum. The proceeds from the issue thus served to ensure the possibility of further growth and sustaining the size of the leverage.

In the case of AAA and VGP issues, they exclusively included the offer of primary shares. The IPO motive may thus be identified in the issuer's zone. Both issuers needed to finance their long-term growth. In the case of VGP (developer), the assets in the afterIPO stage grew by $42.4 \%$, whereas the fixed assets grew by $76 \%$ and there was also an increase in the volume of loans ( $+53 \%)$ and strengthening the leverage. Raising capital for the expansion purposes may also be considered as a primary motive in the case of AAA. The sales in the period before the IPO and in the year of implementing the IPO reached the growth rate of approx. $30 \%$ per year, while in the phase following the IPO, the fixed assets grew by $69 \%$. Even though there was a certain reduction in the leverage, it may be observed that in the period following the IPO, there was a further growth in the received loans (Table 5). In comparison with other IPOs, the need to finance further growth is reflected in the high values of the planned increase in the number of shares ( $25 \%$ or $39 \%$ respectively under the overallotment).

The IPO of the Kofola Company differs from all the IPO groups above. Owing to the amount of the intended sale of the interest of the existing owners (mere 3.7\%), it is among the issues where the motive to implement the IPO was found solely in the issuer's zone (VGP and AAA). However, the intended increase in the number of shares after performing the IPO in the amount of $1 \%$ ranks it among the issues where the IPO motive was found exclusively in the owner's zone (Moneta or E4U). The intended ratio of the offer of primary shares reached $13 \%$, including overallotment. This implies that the prevailing motive was found in the shareholder's sphere. In the case of insufficient interest, however, preference was given to the full satisfaction of the offer of primary shares. Nevertheless, the IPO had a negligible impact on the examined financial indicators. The leverage, the balance sheet sum, and the value of fixed assets remained unchanged following the IPO, yet bank loans increased after the IPO. There was a slight decline in sales in the IPO year and in the immediately following period. The offer of primary shares (even though the intention was completely satisfied in this respect) did not significantly affect the financial and property structure of the issuing company. The IPO volume could not have a more substantial impact. The reasons for implementing the IPO may thus be seen in the non-financial area. The issuer (in this case, a manufacturer of goods intended for end consumers) could strive for raising the visibility in the public eye in this manner (listing the company on a public stock market), and then form one of the possible channels of a future exit. 
Table 6 summarises the primary (and other) motives of the IPOs carried out at the PSE in 2004-2017.

The research results show that the prevailing motive of primary issue was the exit of the owner (the IPOs concerned were also the largest in terms of financial volumes). The IPO was usually carried out by companies with an international investor in their ownership structure, carrying out their business activities outside the territory of the Czech Republic. In many cases, these were entities that used the capital market in the past to obtain financial resources. In several cases, the IPO was launched in the form of a dual listing of shares on the domestic and foreign stock market.

The majority of the initial public offerings had the character of a combined IPO (a total of seven cases), in which investors were offered both primary, as well as secondary shares. Only two IPOs may be considered to be purely primary shares offers (AAA Auto and VGP), and only two were purely secondary offerings (E4U and Moneta). In the case of combined IPOs, the ratio of primary shares in the total offer differed significantly. It may be labelled as very low in the case of NWR, Fortuna and Kofola, while a medium ratio of primary shares was achieved in the case of Zentiva and Pegas, and there was a high ratio of primary shares in the case of ECM. The prevailing motive of the offer of secondary shares consisted in the exit of the venture capital fund, valuation of the investment by selling the shares on the stock exchange and publicity of the company due to the subsequent issue of other shares.

Table 6. Primary motive zone and primary and other IPO motives at the PSE

\begin{tabular}{|l|c|c|c|}
\hline \multicolumn{1}{|c|}{ Issuer } & Primary motive zone & Primary IPO motive & Other IPO motives \\
\hline Moneta & Owner & Exit (subsequently overall) & - \\
\hline E4U & Owner & $\begin{array}{c}\text { Substantial exit (release of funds } \\
\text { while maintaining control) }\end{array}$ & Exit \\
\hline Lobkowicz & Issuer & $\begin{array}{c}\text { Financial stability: debt repay- } \\
\text { ment, reducing the financial lever- } \\
\text { age }\end{array}$ & Substantial exit \\
\hline Pegas & Owner & $\begin{array}{c}\text { Financial stability: reducing } \\
\text { the financial leverage; growth } \\
\text { financing }\end{array}$ \\
\hline NWR & Owner & $\begin{array}{c}\text { Substantial exit (at the stage of a } \\
\text { sharp rise in prices) }\end{array}$ & $\begin{array}{c}\text { Strengthening the financial } \\
\text { stability }\end{array}$ \\
\hline Fortuna & Owner & $\begin{array}{c}\text { Substantial exit (release of funds } \\
\text { while maintaining control) }\end{array}$ & $\begin{array}{c}\text { Publicity and strengthening } \\
\text { the financial stability }\end{array}$ \\
\hline Zentiva & Owner & Partial exit following an acquisi- \\
tion & $\begin{array}{c}\text { Financial stability: debt repay- } \\
\text { ment, reducing the financial } \\
\text { lever; ensuring further growth }\end{array}$ \\
\hline ECM & Issuer & Ensuring further growth & Partial exit \\
\hline Kofola & Issuer & IPO-related publicity & $\begin{array}{c}\text { Possible path to future exist } \\
\text { or funds }\end{array}$ \\
\hline VGP & Issuer & Ensuring further growth & - \\
\hline AAA & Issuer & Ensuring further growth & - \\
\hline Source: & & &
\end{tabular}

Source: own study.

It is also important that the planned intentions of the issue were not always satisfied. This applies in particular to the insufficient demand in the case of the IPO of Pivovary 
Lobkowicz. The results were also affected by the share options granted to issuers' managers. The decision on which part of the offer was preferred in the absence of investor interest represents another result indicating the IPO motive zone.

In accordance with financial theories and empirical findings that view an IPO not only as a source of financing but also as channel allowing shareholders to cash out and as a tool how to enhance the company's publicity (Pagano et al., 1998; Maksimovic \& Pichler, 2001; Helwege \& Liang, 2004), we suggest that companies launching the Prague Stock Exchange in recent years were predominantly determined by non-financial aspects. These findings are also consistent with the survey carried out by Meluzín and Zinecker (2014) and Meluzín et al. (2016), who report that one of the main IPO motivation perceived by Polish managers was to enhance 'publicity and corporate image', to increase attractiveness of the company as an employer and to establish the company market value.

\section{CONCLUSIONS}

In order to evaluate the prevailing motives for the IPO launch at the PSE in the period 2004-2017, we designed and applied a set of composite indicators the values of which may be understood as an indication of the extent to which IPO launch motives originate in the zone of the issuing company's needs or in the zone of interest of its owner (owners).

We believe that our composite indicators allow to assess not only the predominant IPO motive zone, but also measure the intensity of the motives. This allows better assessment of the urgency of the needs of the issuing companies satisfied by the IPO implementation. The open question remains whether the prevailing IPO motives on the part of the issuing company cannot serve as a precursor of possible future risks for potential investors. Research results show that companies with the prevailing intensity of the motive on the issuer's side (ECM or AAA) faced a significant decline in the value of the issued shares in the future.

In conclusion, it may be stated that in the last decade, the IPOs carried out at the PSE mainly served for the exit of investors, usually selling minority stakes through the IPO, while maintaining control over the issuers (with the exception of Moneta). Raising capital for further development of the company as the primary motive of the IPO implementation was minor, with the tendency of being applied in smaller issuers. However, even in the case of these IPOs, the principle of maintaining control of the original owner over the issuer was applied.

Although the survey methodology proposed and used here reveals new insights into going public motivation, it is also undoubtedly a source of some limitations. Because the sample size is too small, we cannot apply statistical tests to identify whether significant relationships within data set exist. We analysed enterprises operating in a specific macroeconomic and institutional environment, which might have affected the going public motivation.

In follow-up research, we aim to test the proposed methodological approach within a longitudinal research study; thus, the data for upcoming IPOs will be gathered and the methodological tools will be applied and refined if necessary. Using panel data involving more countries might represent another direction for a future research.

\section{REFERENCES}

Auret, C., \& Britten, J. (2008). Post-issue operating performance of firms listing on the JSE. Investment Analysts Journal, 37(68), 21-29. https://doi.org/10.1080/10293523.2008.11082501 
Balcerzak, A.P., Kliestik, T., Streimikiene, D., \& Smrčka, L. (2017). Non-parametric approach to measuring the efficiency of banking sectors in European Union Countries. Acta Polytechnica Hungarica, 14(7), 51-70. https://doi.org/10.12700/APH.14.7.2017.7.4

Bloomberg L.P. Balance and Income Statement. Retrieved on January 8, 2018 from Bloomberg database.

Brau, J., Francis, B., \& Kohers N. (2003). The Choice of IPO versus Takeover: Empirical Evidence. The Journal of Business, 76(4), 583-612. https://doi.org/10.1086/377032

Brau, J.C., \& Fawcett, S.E. (2006). Initial Public Offerings: An Analysis of Theory and Practice. The Journal of Finance, 61(1), 399-436. https://doi.org/10.1111/j.1540-6261.2006.00840.x

Breinlinger, L., \& Glogova, E. (2002). Determinants of Initial Public Offerings: A European Time-Series CrossSection Analysis. Wien: Oesterreichische Nationalbank, Working Paper, Financial Stability Report.

Chemmanur, T.J., \& Fulghiery, A. (1999). Theory of the Going-Public Decision. Review of Financial Studies, 12(2), 249-79. https://doi.org/10.1093/rfs/12.2.249

European Commission. (2012). Entrepreneurship 2020 Action Plan.

Fontinelle, A. (2015). IPO vs. Staying Private: Pros \& Cons of Each Model. Retrieved on September 1, 2018 from http://www.investopedia.com/articles/investing/102915/ipo-vs-staying-privatepros-and-cons-each-model.asp

Helwege, J., \& Liang, N. (2004). Initial Public Offering in Hot and Cold Markets. Journal of financial and quantitative analysis, 39(3), 541-569. https://doi.org/10.1017/S0022109000004026

Isniawati, A., Rahmawati, R., \& Gunardi, A. (2018). Information asymmetry and accounting conservatism: Does analyst coverage moderate the results?. Journal of International Studies, 11(3), 176190. https://doi.org/10.14254/2071-8330.2018/11-3/15

Ivanová, E. (2017). Barriers to the development of SMEs in the Slovak Republic. Oeconomia Copernicana, 8(2), 255-272. https://doi.org/10.24136/oc.v8i2.16

Kim, W., \& Weisbach, M. (2008). Motivations for public equity offers: An international perspective. Journal of Financial Economics, 87(2), 281-307. https://doi.org/10.1016/j.jfineco.2006.09.010

Kljucnikov, A., \& Belas, J. (2016). Approaches of Czech entrepreneurs to debt financing and management of credit risk. Equilibrium. Quarterly Journal of Economics and Economic Policy, 11(2), 343365. https://doi.org/10.12775/EQUIL.2016.016

Loughran, T., \& Ritter, J. (1995). The New Issues Puzzle. The Journal of Finance, 50(1), 23-51. https://doi.org/10.2307/2329238

Ljungqvist, A.P. (1995). When Do Firms Go Public? Poisson Evidence from Germany. University of Oxford, Working Paper.

Lyócsa, S. (2014). Growth-Returns Nexus: Evidence from Three Central and Eastern European Countries. Economic Modelling, 42, 343-55. https://doi.org/10.1016/j.econmod.2014.07.023

Mackevičius, J., Šneidere, R., \& Tamulevičienè, D. (2018). The waves of enterprises bankruptcy and the factors that determine them: the case of Latvia and Lithuania. Entrepreneurship and Sustainability Issues, 6(1), 100-114. https://doi.org/10.9770/jesi.2018.6.1(8)

Maksimovic, V., \& Pichler, P. (2001). Technological innovation and initial public offerings. The Review of Financial Studies, 14(2), 459-494. https://doi.org/10.1093/rfs/14.2.459

Meluzín, T., Balcerzak, A.P., Pietrzak, M.B., Zinecker, M., \& Doubravský, K. (2018a). The Impact of Rumours Related to Political and Macroeconomic Uncertainty on IPO Success: Evidence from a Qualitative Model. Transformations in Business \& Economics, 17(2), 148-69.

Meluzín, T., Zinecker, M., Balcerzak, A.P., Doubravský, K., Pietrzak, M.B., \& Dohnal, M. (2018b). The Timing of Initial Public Offerings: Non-Numerical Model Based on Qualitative Trends. Journal of Business Economics and Management, 19(1), 63-79. https://doi.org/10.3846/jbem.2018.1539 
Meluzín, T., Zinecker, M., \& Lace, N. (2016). Going Public: Key Factors to Consider by IPO Candidates on Emerging Markets of Poland and the Czech Republic. Engineering Economics, 27(4), 392-404. https://doi.org/10.5755/j01.ee.27.4.14755

Meluzín, T., Pietrzak, M.B., Balcerzak, A.P., Zinecker, M., Doubravský, K., \& Dohnal, M. (2017). Rumours Related to Political Instability and their Impact on IPOs: The Use of Qualitative Modeling with Incomplete Knowledge. Polish Journal of Management Studies, 16(2), 171-187. https://doi.org/10.17512/pjms.2017.16.2.15

Meluzín, T., \& Zinecker, M. (2014). Research into Determinants Influencing IPO Decisions on the Polish Capital Market. Betriebswirtschaftliche Forschung Und Praxis (Bfup), 66(6), 294-301.

Meluzín, T., \& Zinecker, M. (2016). Trends in IPOS: the evidence from cee capital markets. Equilibrium. Quarterly Journal of Economics and Economic Policy, 11(2), 327-341. https://doi.org/10.12775/EQUIL.2016.015

Mentel, G., Brożyna, J., \& Szetela, B. (2017). Evaluation of the effectiveness of investment fund deposits in Poland in a time of crisis. Journal of International Studies, 10(2), 46-60. https://doi.org/10.14254/2071-8330.2017/10-2/3

Michalak, A. (2016). The cost of capital in the effectiveness assessment of financial management in a company. Oeconomia Copernicana, 7(2), 317-329. https://doi.org/10.12775/OeC.2016.019

Myers, S. (1984). The Capital Structure Puzzle. The Journal of Finance, 39(3), 575-592. https://doi.org/10.2307/2327916

Myers, S., \& Majluf, N. (1984). Corporate Financing and Investment Decisions When Firms Have Information That Investors Do Not Have. Journal of Financial Economics, 13(2), 187-221. https://doi.org/10.1016/0304-405X(84)90023-0

Nicolescu, L., \& Tudorache, F.G. (2017). Capital markets in Central and Eastern Europe: two selected cases. In Proceedings of the 11th International Conference on Business Excellence. De Gruyter, 597-606.

Pagano, M., Panetta, F., \& Zingales, L. (1998). Why Do Companies Go Public? An Empirical Analysis. The Journal of Finance, 53(1), 27-64. https://doi.org/10.1111/0022-1082.25448

Paeglis, I., \& Veeren, P. (2013). Speed and consequences of venture capitalist post-IPO exit. Journal of Corporate Finance, 22(1), 104-123. https://doi.org/10.1016/j.jcorpfin.2013.04.005

Peterle, P., \& Berk, A. (2016). IPO Cycles in Central and Eastern Europe: What Factors Drive These Cycles?. Czech Journal of Economics and Finance, 66(2), 113-39.

Pratt, S., \& Grabowski, R. (2008). Cost of Capital. 3rd ed. Hoboken: Wiley.

Ritter, J. (1991). The Long-Run Performance of Initial Public Offerings. The Journal of Finance, 46(1), 3-27. https://doi.org/10.2307/2328687

Ritter, J.R. (2011). Equilibrium in the IPO Market. Financial Economics, 3, 347-74. https://doi.org/10.2139/ssrn.1822542

Röell, A. (1996). The decision to go public. European Economic Review, 40(3), 1071-1081. https://doi.org/10.1016/0014-2921(95)00114-X

Roženský, J. (2008). IPO na středoevropských akciových trzích (IPO on Central European Stock Markets). Prague: Charles University, Faculty of Social Sciences.

Rydqvist, K., \& Högholm, K. (1995). Going public in the 1980s. European Financial Management, 1(3), 287-315. https://doi.org/10.1111/j.1468-036X.1995.tb00021.x

Skalická Dušátková, M., Zinecker, M., \& Meluzín, T. (2017). Institutional Determinants of Private Equity Market in Czech Republic. Economics and Sociology, 10(4), 83-98. https://doi.org/10.14254/2071-789X.2017/10-4/7

Sullivan, B. (1965). An Introduction to "Going Public". Journal of Accountancy, 120(5), 48-53. 
Valaskova, K., Kliestik, T., \& Kovacova, M. (2018). Management of financial risks in Slovak enterprises using regression analysis. Oeconomia Copernicana, 9(1), 105-121. https://doi.org/10.24136/oc.2018.006

Vasilescu, A.M., Dima, A.M., \& Vasilache, S. (2009). Credit analysis policies in construction project finance. Management \& Marketing, 4(2), 79-94.

Zemguliene, J., \& Valukonis, M. (2018). Structured literature review on business process performance analysis and evaluation. Entrepreneurship and Sustainability Issues, 6(1), 226-252. https://doi.org/ 10.9770/jesi.2018.6.1(15) 
Appendix A: Main characteristics of the IPOs carried out at the PSE in 2004-2017

\begin{tabular}{|c|c|c|c|c|c|c|c|c|c|c|c|}
\hline \multirow{2}{*}{$\begin{array}{l}\text { IPO char- } \\
\text { acteristics }\end{array}$} & \multicolumn{11}{|c|}{ Issuing companies } \\
\hline & Zentiva & ECM & Pegas & AAA & VGP & NWR & Fortuna & E4U & \begin{tabular}{|c} 
Lobko- \\
wicz
\end{tabular} & $\begin{array}{l}\text { Ko- } \\
\text { fola }\end{array}$ & $\begin{array}{c}\text { Mone- } \\
\text { ta }\end{array}$ \\
\hline IPO date & $\begin{array}{c}28 / 06 / \\
2004\end{array}$ & $\begin{array}{c}07 / 12 / \\
2006\end{array}$ & $\begin{array}{c}18 / 12 / \\
2006\end{array}$ & $\begin{array}{c}24 / 09 / \\
2007\end{array}$ & $\begin{array}{c}07 / 12 / \\
2007\end{array}$ & $\begin{array}{c}06 / 05 / \\
2008\end{array}$ & $\begin{array}{c}22 / 10 / \\
2010\end{array}$ & $\begin{array}{c}25 / 08 / \\
2011\end{array}$ & $\begin{array}{c}28 / 05 / \\
2014\end{array}$ & $\begin{array}{l}02 / 12 \\
/ 2015\end{array}$ & $\begin{array}{l}6 / 5 / \\
2016\end{array}$ \\
\hline $\begin{array}{l}\text { Offer char- } \\
\text { acter }\end{array}$ & $\begin{array}{l}\text { Com- } \\
\text { bined }\end{array}$ & $\begin{array}{l}\text { Com- } \\
\text { bined }\end{array}$ & $\begin{array}{l}\text { Com- } \\
\text { bined }\end{array}$ & Primary & Primary & $\begin{array}{l}\text { Com- } \\
\text { bined }\end{array}$ & $\begin{array}{l}\text { Com- } \\
\text { bined }\end{array}$ & $\begin{array}{c}\text { Second- } \\
\text { ary }\end{array}$ & $\begin{array}{l}\text { Com- } \\
\text { bined }\end{array}$ & $\begin{array}{l}\text { Com- } \\
\text { bined }\end{array}$ & $\begin{array}{c}\text { Second- } \\
\text { ary }\end{array}$ \\
\hline \multicolumn{12}{|c|}{ IPO structure (subscriptions of shares in thousands) } \\
\hline $\begin{array}{l}\text { Primary } \\
\text { shares }\end{array}$ & $4,329.90$ & $1,275.00$ & $1,810.00$ & $17,757.8$ & $3,278.69$ & $13,500.0$ & $2,000.00$ & 0.00 & $2,300.00$ & 275.0 & 0.00 \\
\hline $\begin{array}{l}\text { Increase } \\
\text { option }\end{array}$ & 0.00 & 127.50 & 0.00 & 0.00 & 304.36 & 0.00 & 0.00 & 0.00 & 110.00 & 0.00 & 0.00 \\
\hline $\begin{array}{l}\text { Secondary } \\
\text { shares }\end{array}$ & $5,670.10$ & 315.03 & $2,575.00$ & 0.00 & 0.00 & $69,513.3$ & $13,830.0$ & $1,171.90$ & 0.00 & 825.0 & 260,610 \\
\hline $\begin{array}{l}\text { Increase } \\
\text { option }\end{array}$ & $1,500.00$ & 0.00 & 657.75 & 0.00 & 0.00 & $12,452.0$ & $1,194.67$ & 0.00 & 0.00 & 400.0 & 33,113 \\
\hline $\begin{array}{l}\text { Subscribed } \\
\text { shares (to- } \\
\text { tal) }\end{array}$ & $11,500.0$ & $1,717.53$ & $5,042.75$ & 17,758 & $3,583.05$ & $95,465.4$ & $17,024.7$ & $7,171.90$ & $2,410.00$ & 1,500 & 293,723 \\
\hline $\begin{array}{l}\text { No of } \\
\text { shares be- } \\
\text { fore the } \\
\text { IPO }\end{array}$ & $33,806.3$ & $2,460.00$ & $7,419.40$ & $50,000.0$ & $15,000.0$ & 250,240 & 52,000 & $2,391.64$ & $9,388.00$ & $\begin{array}{r}22,02 \\
0\end{array}$ & 511,000 \\
\hline $\begin{array}{l}\text { No of } \\
\text { shares af- } \\
\text { ter the IPO }\end{array}$ & $38,136.2$ & $3,862.50$ & $9,229.40$ & $67,757.9$ & $18,583.1$ & 263,740 & 54,000 & $2,391.64$ & $11,797.5$ & $\begin{array}{r}22,29 \\
5\end{array}$ & 511,000 \\
\hline $\begin{array}{l}\text { Free float } \\
(\%)\end{array}$ & 30.16 & 44.47 & 54.64 & 26.21 & 3.28 & 36.20 & 35.00 & 49.00 & 20.62 & 6.72 & 51.00 \\
\hline \multicolumn{12}{|c|}{ Structure of investors(\%), IPO costs and underpricing } \\
\hline \begin{tabular}{|l} 
Institu- \\
tional
\end{tabular} & 100.00 & 90.00 & 90.00 & 61.00 & - & 90.00 & 90.00 & - & 44.00 & 83.00 & 96.70 \\
\hline \begin{tabular}{|l|} 
Retail \\
\end{tabular} & 0.00 & 10.00 & 10.00 & 39.00 & 17.00 & 10.00 & 10.00 & - & 56.00 & 17.00 & 3.30 \\
\hline $\begin{array}{l}\text { Issue price } \\
(€ / \text { share })\end{array}$ & 15.21 & 47.00 & 27.00 & 2.00 & 15.25 & 16.56 & 4.29 & 3.30 & 5.83 & 19.83 & 2.52 \\
\hline $\begin{array}{l}\text { Issue size } \\
\text { (thou- } \\
\text { sands } € \text { ) }\end{array}$ & 174,915 & $80,723.9$ & 136,154 & $35,515.7$ & $54,641.5$ & $1,580,906$ & 72,952 & $3,868.45$ & $14,052.5$ & 29,737 & 739.199 \\
\hline \begin{tabular}{|l}
$\begin{array}{l}\text { Direct IPO } \\
\text { costs (\%) }\end{array}$ \\
\end{tabular} & 6.60 & 6.86 & 7.28 & 6.76 & 9.00 & 5.61 & 2.74 & 1.28 & 5.03 & 4.87 & 0.32 \\
\hline $\begin{array}{l}\text { Underpric- } \\
\text { ing (\%) }\end{array}$ & 4.01 & 11.70 & 4.52 & 0.05 & 2.30 & 7.55 & 0.45 & 8.00 & 1.75 & 0.98 & 0.07 \\
\hline
\end{tabular}

Source: own elaboration based on prospectus reports.

The copyediting and proofreading of articles in English is financed in the framework

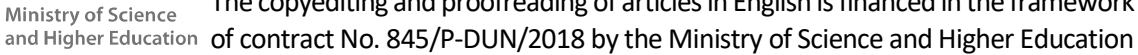
Republic of Poland $\quad$ of the Republic of Poland committed to activities aimed at science promotion. 


\section{Authors}

Contribution share of authors is as follows: Martina Skalická (50\%), Marek Zinecker (20\%), Adam P. Balcerzak (15\%) and Tomáš Meluzín (15\%).

\section{Martina Skalická}

Martina Skalická is an assistance professor at the Brno University of Technology, Faculty of Business and Management. Her research interests include corporate economics, in particular private and public equity.

Correspondence to: Martina Skalická, Brno University of Technology, Faculty of Business and Management, Kolejní 2906/4, 61200 Brno, Czech Republic, e-mail: skalicka@fbm.vutbr.cz ORCID (i) http://orcid.org/0000-0002-4985-554X

\section{Marek Zinecker}

Marek Zinecker is an associate professor at the Brno University of Technology, Faculty of Business and Management. His research interests include macroeconomics and international economics.

Correspondence to: Marek Zinecker, Brno University of Technology, Faculty of Business and Management, Kolejní 2906/4, 61200 Brno, Czech Republic, e-mail: zinecker@fbm.vutbr.cz ORCID (1) http://orcid.org/0000-0003-1764-0904

\section{Adam P. Balcerzak}

Adam P. Balcerzak is an assistance professor at the Nicolaus Copernicus University, Faculty of Economic Sciences and Management. His research interests include macroeconomics and financial markets.

Correspondence to: Adam P. Balcerzak, Nicolaus Copernicus University, Faculty of Economic Sciences and Management, ul. Gagarina 13A; 87-100 Toruń, Poland, e-mail: adam.balcerzak@umk.pl ORCID (1) http://orcid.org/0000-0003-0352-1373

\section{Tomáš Meluzín}

Tomáš Meluzín is an associate professor at the Brno University of Technology, Faculty of Business and Management. His research interests include corporate economics and capital markets.

Correspondence to: Tomáš Meluzín, Brno University of Technology, Faculty of Business and Management, Kolejní 2906/4, 61200 Brno, Czech Republic, e-mail: meluzint@fbm.vutbr.cz ORCID (1) http://orcid.org/0000-0001-5238-5166

\section{Acknowledgements and Financial Disclosure}

The article came into being within the project no. 2016/1 entitled 'Analysis of Relations among Capital Markets of the European Union Countries' financed by the Institute of Economic Research Toruń, Poland, and Brno University of Technology, Faculty of Business and Management, Czech Republic conducted in the years 2016-2018.

We are grateful to the editor and to two anonymous referees whose comments significantly improved the paper.

\section{Copyright and License}

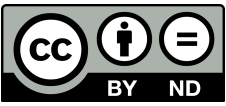

This article is published under the terms of the Creative Commons Attribution - NoDerivs (CC BY-ND 4.0) License http://creativecommons.org/licenses/by-nd/4.0/ 
